\title{
Effectiveness of C1-INH therapy in angiotensin converting enzyme inhibitor induced angioedema
}

\author{
Uliana Kovaltchouk ${ }^{1 *} \mathbb{D}$, Boyang Zhang ${ }^{2}$, Vipul Jain ${ }^{3}$ and Chrystyna Kalicinsky ${ }^{4}$
}

\begin{abstract}
Introduction: Angiotensin Converting Enzyme Inhibitors (ACEI) are a common cause of Emergency Room presentation for angioedema. Although no treatment guidelines exist, $\mathrm{C}$ esterase inhibitor concentrate (C1-INH) is used on an off label basis for management of ACEl acquired angioedema (ACEI AAE).

Objective: To evaluate the efficacy of C1-INH in management of ACEI AAE at our local centers.

Results: Nine patients, from 3 academic sites, were identified through Allergy Service consultation data and records from Diagnostic Services Manitoba, Canada from 2010-2020. The majority of the patients $(n=8 / 9)$ required endotracheal intubation prior to the initiation of $\mathrm{C} 1-\mathrm{INH}$. Overall, approximately $56 \%$ of patients $(n=5 / 9)$ had resolution of angioedema ranging between 12 and $17 \mathrm{~h}$, with a median time of $13.5 \mathrm{~h}$, and no recurrence after the administration of $\mathrm{C1}$-INH concentrate. One patient had transient symptom resolution in $14 \mathrm{~h}$, however, recurrence of angioedema required re-intubation. The remainder of patients $(n=4 / 9)$, had resolution of angioedema between 22 and $72 \mathrm{~h}$, with a median time of $33.75 \mathrm{~h}$.

Conclusion: Our findings demonstrate continued ambivalence of the efficacy and role of C1-INH concentrate in the treatment of ACEI AAE, secondary to multiple uncontrolled confounding factors. Further research into characterizing a subgroup of intubated patients in our study that responded to $\mathrm{C} 1$-INH concentrate needs to be completed.
\end{abstract}

\section{Background}

Angiotensin Converting Enzyme Inhibitors (ACEI) are prescribed to over 40 million people for various indications, including heart failure, diabetes, chronic kidney disease, hypertension, and myocardial infarction [1]. Angioedema is a well-documented side effect of ACEI, affecting approximately $1 \%$ of patients, and is the leading cause of drug-induced angioedema emergency room visits [2-4]. The underlying physiological mechanism has been shown to be secondary to an excess of bradykinin and substance $P$, due to the inhibition of their degradation by ACE $[5,6]$. There is no consensus

\footnotetext{
*Correspondence: umkovalt@myumanitoba.ca

${ }^{1}$ Internal medicine, University of Manitoba, Winnipeg, Canada

Full list of author information is available at the end of the article
}

on the best pharmacologic approach to managing patients with ACEI induced angioedema, nor is there any approved targeted treatment [7, 8]. Traditional pharmacological treatment modalities include antihistamines, steroids, epinephrine, all of which have been shown to be generally ineffective [9-11]. Without treatment, the edema typically resolves over $24-48 \mathrm{~h}$, but, may take up to five days [12]. When symptoms of ACEI angioedema progress to threaten the airway, previous case reports and case series have described using bradykinin targeted treatments, including $\mathrm{C} 1$ esterase inhibitor (C1-INH) concentrate [11, 13-15]. The use of CI-INH concentrate) is controversial, given no phase 3 clinical studies have been performed to show its utility in managing ACEI angioedema. It currently remains an offlabel treatment from its approved treatment indication 
for hereditary induced angioedema. Given the incidence of emergency room visits secondary to adverse reactions to ACEI, further assessment of the efficacy and utility of $\mathrm{C} 1-\mathrm{INH}$ concentrate in acute management is warranted.

\section{Methods}

A retrospective chart review, from three academic hospitals in Winnipeg, Manitoba, was conducted examining all patients with ACEI induced angioedema, who received C1-INH treatment, between 2010 and 2020. This study was approved by the University of Manitoba Research Ethics Board. The inclusion criteria were as follows: patients must have been taking an ACEI at the time of developing angioedema, and have received C1-INH concentrate at one of the academic hospitals. The exclusion criteria was identifying angioedema caused by any other etiology. Data collected included patient demographics, medical indication for ACEI, alternative angioedema treatment prior to $\mathrm{C} 1-\mathrm{INH}$ concentrate administration, time of C1-INH concentrate administration, dose and number of doses of C1-INH concentrate administered, need for intubation, and time to symptom resolution after $\mathrm{C} 1-\mathrm{INH}$ concentrate administration.

\section{Results}

Nine patients were identified through Allergy Service consultation data and records from Diagnostic Services Manitoba, Canada from 2010 to 2020. The majority of patients identified were female $(n=6 / 9)$, and of Caucasian ethnicity $(n=8 / 9)$, with the exception of one Filipino patient. Three patients received ACEi therapy with ramipril, two with perindopril, two with enalapril, one with lisinopril, and one with quinapril. Less than half of the patients analyzed were being treated with NSAIDs at the time of developing angioedema $(n=4 / 9)$. All patient suffered from hypertension, with five patients also having a concomitant diagnosis of diabetes. All patients had an acute angioedema attack of the upper airway or face, including lips, tongue, soft palate, and/ or cheeks. Initial management of all patients was with methylprednisolone (dosed between 60-80 mg IV), IV diphenhydramine (dosed at $50 \mathrm{mg}$ ) and epinephrine (dosed between $0.1 \mathrm{mg}$ IV or, $0.3-0.5 \mathrm{mg}$ IM), either by paramedics, or emergency room physicians at the time of presentation. The majority of the patients $(n=7 / 9)$ required endotracheal intubation prior to the initiation of C1-INH concentrate for airway protection. The time to receiving $\mathrm{C} 1-\mathrm{INH}$ concentrate in the emergency room was highly variable, with the range being between 1 and $25 \mathrm{~h}$ (median $8.25 \mathrm{~h}$ ). The first dose of C1-INH concentrate provided was 20 units $/ \mathrm{kg}$, with doses ranging from 1000 to $1500 \mathrm{IU}$. Three patients received an additional dose of C1-INH concentrate: one patient received an additional $500 \mathrm{IU}$, while the remaining two patients received $1000 \mathrm{IU}$. One patient was initially managed with one dose of C1-INH concentrate $1500 \mathrm{IU}$, however, went on $4 \mathrm{~h}$ later to receive one dose of Icabitant $30 \mathrm{mg}$ subcutaneously, given minimal initial response to $\mathrm{C} 1-\mathrm{INH}$ concentrate treatment. This patient was extubated $26 \mathrm{~h}$ after receiving both C1-INH concentrate and Icabitant. Overall, approximately $44 \%$ of patients $(n=4 / 9)$ had resolution of angioedema ranging between 12 and $14 \mathrm{~h}$, with a median time of $12.75 \mathrm{~h}$, and no recurrence. One patient had transient symptom resolution in $14 \mathrm{~h}$, however, recurrence of angioedema $24 \mathrm{~h}$ later, requiring re-intubation. The remainder of patients $(n=4 / 9)$, had resolution of angioedema between 22 and $72 \mathrm{~h}$, with a median time of $33.75 \mathrm{~h}$. Summary of these findings are found in Table 1.

\section{Discussion}

The evidence supporting use of $\mathrm{C} 1-\mathrm{INH}$ concentrate, or Berinert, for ACEI AAE is limited in the current medical literature. Previous case and small case series reports have shown highly variable symptom response, no significant prevention of endotracheal intubation, and no reduction in the time spent in the intensive care unit [11, 13-15]. Despite our study not being designed as an interventional trial, our findings are unique from previous case series described, in that the majority of the patients analyzed were intubated for airway protection, prior to C1-INH concentrate treatment. Additionally, our findings of symptom resolution, which we have defined as time to extubation, were dichotomous, with approximately half of patients improving within $12 \mathrm{~h}$, and the other half over $24 \mathrm{~h}$. C1-INH functions through inactivating plasma kallikrein and factor XIIa, which raises the question of whether the dichotomy could be explained by variations in levels of both of these factors in patients admitted to the intensive care unit. Additionally, there was a trend that patients being treated with NSAIDs at the time of developing the angioedema, responded slower to the $\mathrm{C} 1-\mathrm{INH}$ treatment. This raises the question of whether there was a multifactorial etiology, or alternative explanation of the angioedema in these patients, given the mechanism of NSAID induced angioedema is through shunting of arachidonic acid towards the 5-lipoxygenase pathway, resulting in increased synthesis of cysteinyl leukotrienes [16]. Given the limited number of patients analyzed, a significant correlation between the time of administration of C1-INH concentrate, and subsequent time to symptom resolution, was not able to be made, in terms of specific patient characteristics. However, given that no adverse reactions to $\mathrm{C} 1-\mathrm{INH}$ concentrate were documented, 
Table 1 Summary of demographic findings and timing of C1-INH administration, dose, and time to angioedema resolution (marked by time to extubation)

\begin{tabular}{|c|c|c|c|c|c|c|c|c|}
\hline Case & Age & Sex & ACEi & Diabetes & NSAIDs & $\begin{array}{l}\text { Time from onset of symptoms to drug } \\
\text { administration }\end{array}$ & Dose of Berinert & Time to Resolution of symptoms \\
\hline 1 & 80 & $\mathrm{~F}$ & Ramipril & No & No & $6.5 \mathrm{~h}$ & $1500 \mathrm{IU}$ & $12.5 \mathrm{~h}$ \\
\hline 2 & 57 & $\mathrm{~F}$ & Ramipril & No & No & $22 \mathrm{~h}$ & $1500 \mathrm{IU}$ & $12 \mathrm{~h}$ \\
\hline 3 & 67 & $\mathrm{~F}$ & Perindopril & Yes & Yes & $9.5 \mathrm{~h}$ & $\begin{array}{l}1000 \mathrm{IU} \\
500 \mathrm{IU}\end{array}$ & $35 \mathrm{~h}$ \\
\hline 4 & 70 & M & Perindopril & Yes & Yes & $1 \mathrm{~h}$ & $1500 \mathrm{IU}$ & $32.5 \mathrm{~h}$ \\
\hline 5 & 77 & M & Quinapril & Yes & Yes & $7 \mathrm{~h}$ & $1500 \mathrm{IU}$ & $72 \mathrm{~h}$ \\
\hline 6 & 62 & $\mathrm{~F}$ & Lisinopril & No & No & $\begin{array}{l}5 \mathrm{~h} \\
\text { Recurrence of symptoms } 24 \mathrm{~h} \text { later } \rightarrow \\
\quad 4 \mathrm{~h}\end{array}$ & $\begin{array}{l}1500 I U \\
1000 I U\end{array}$ & $\begin{array}{l}14 \mathrm{~h} \\
26 \mathrm{~h}\end{array}$ \\
\hline 7 & 64 & $\mathrm{~F}$ & Enalapril & No & No & $25 \mathrm{~h}$ & $1000 \mathrm{IU}$ & $13 \mathrm{~h}$ \\
\hline 8 & 67 & $\mathrm{~F}$ & Ramipril & Yes & No & $10 \mathrm{~h}$ & $1500 \mathrm{IU}$ & $\begin{array}{l}\text { No response within } 4 \mathrm{~h} \rightarrow \\
\text { received } 30 \mathrm{mg} \text { Icabitant } \rightarrow \\
22 \mathrm{~h}\end{array}$ \\
\hline 9 & 70 & M & Enalapril & Yes & No & $11 \mathrm{~h}$ & $1500 \mathrm{IU}$ & $14 \mathrm{~h}$ \\
\hline
\end{tabular}

it can be speculated that in a subgroup of intubated patients, C1-INH concentrate treatment does shorten the duration of symptoms, and leads to a reduction in time being intubated. Providing an additional dose of C1-INH concentrate after a period of no response from an initial dose, also, did not improve time to resolution of symptoms in two patients, with the times to symptom resolution being at 35 and $72 \mathrm{~h}$. This suggests that if a response to $\mathrm{C} 1-\mathrm{INH}$ concentrate treatment will be seen, it will be with the first dose. Major limitations to this study revolve around the study being retrospective in nature. Our small sample size is reflective of the overall infrequent presentation of ACEI AAE. Factors such as angioedema that may have been secondary to NSAIDs or histamine mediated angioedema were not able to be accounted for asides from preliminary demographic screening (screening patients who on history were on an ACEI and developed angioedema without a clear alternative cause for their angioedema). The use of epinephrine, corticosteroids, and antihistamines prior to the administration of C1-INH concentrate are additional confounders in this study-however, the administration of all of these were done prior to intubation. Given no response to the above treatment, and the history being unrevealing, it was assumed that histaminergic or mast cell-mediated angioedema was not a significant confounding variable in this study.

\section{Conclusions}

ACEI angioedema is a severe and potentially fatal side effect. As ACEI are still widely used worldwide for a variety of medical conditions, an optimal management strategy for patients experiencing acute ACEi angioedema is needed. To date, there is no specific pharmacological intervention that has been approved. This study adds to the current medical literature, as we have specifically investigated the efficacy of C1-INH concentrate administration in patients who have been intubated for airway protection from ACEi induced angioedema. Although our preliminary findings suggest that $\mathrm{C} 1-\mathrm{INH}$ concentrate administration may shorten the time spent in the intensive care unit in a subgroup of patients, this conclusion must be met with caution given multiple confounding variables. Ultimately, further research into characterizing this subgroup of patients needs to be completed.

\section{Acknowledgements \\ we would like to thank Dr. Chrystyna Kalicinsky for her assistance and guidance in this research.}

\section{Authors' contributions}

UK was involved in researching the literature and writing the first draft of the manuscript. All authors reviewed and edited the manuscript and approved the final version of the manuscript.

\section{Funding}

This research received no specific grant from any funding agency in the public, commercial, or not-for-profit sectors.

\section{Availability of data and materials}

Data results reported in this manuscript are stored on a private, password, and virus-protected computer, and, are available on reasonable request. No hyperlinks to publicly archived datasets have been generated during the study.

Ethics approval and consent to participate

Ethics approval was received from the University of Manitoba health research ethics board. 


\section{Consent for publication}

The University of Manitoba health research ethics board has provided us with consent for publication.

\section{Competing interests}

There are no competing interests from either of the authors listed.

\section{Author details}

${ }^{1}$ Internal medicine, University of Manitoba, Winnipeg, Canada. ${ }^{2}$ Max Rady College of Medicine, University of Manitoba, Winnipeg, Canada. ${ }^{3}$ Clinal Immunology and Allergy, McMaster University, Hamilton, Canada. ${ }^{4}$ Allergy and Immunology, University of Manitoba, Winnipeg, Canada.

Received: 12 June 2020 Accepted: 29 January 2021

Published online: 15 February 2021

\section{References}

1. Terreehorst I, Reitsma S, Cohn DM. Current Treatment of Angioedema Induced by ACE Inhibitors. Curr Treat Options Allergy. 2019;6(1):18-26.

2. Rasmussen ER, Mey K, Bygum A. Angiotensin-converting enzyme inhibitor-induced angioedema — a dangerous new epidemic. Acta Derm Venereol. 2014:94(3):260-4.

3. Kostis JB, Packer M, Black HR, Schmieder R, Henry D, Levy E. Omapatrilat and enalapril in patients with hypertension: the Omapatrilat Cardiovascular Treatment vs. Enalapril (OCTAVE) trial. Am J Hypertens. 2004;17(2):103-11.

4. Montinaro V, Cicardi M. ACE inhibitor-mediated angioedema. Int Immunopharmacol. 2020. https://doi.org/10.1016/j.intimp.2019.106081.

5. Nussberger J, Cugno M, Amustutz C, Cicardi M, Pellacani A, Agostoni A. Plasma bradykinin in angio-oedema. Lancet. 1998;351(9117):1693-7.

6. Byrd JB, Touzin K, Sile S, Gainer JV, Yu C, Nadeau J, Adam A, Brown NJ. Dipeptidyl peptidase IV in angiotensin-converting enzyme inhibitor associated angioedema. Hypertension. 2008;51(1):141-7.

7. Kostis WJ, Shetty M, Chowdury YS, Kostis JB. ACE Inhibitor-induced angioedema: a review. Curr Hypertens Rep. 2018;20(7):55.

8. Craig TJ, Bernstein JA, Farkas H, Bouillet L, Boccon-Gibod I. Diagnosis and treatment of bradykinin-mediated angioedema: outcomes from an angioedema expert consensus meeting. Int Arch Allergy Immunol. 2014;165(2):119-27.

9. Lieberman P, Nicklas RA, Oppenheimer J, Kemp SF, Lang DM, Bernstein DI, Bernstein JA, Burks AW, Feldweg AM, Fink JN, Greenberger PA, Golden DB, James JM, Kemp SF, Ledford DK, Lieberman P, Sheffer AL, Bernstein DI, Blessing-Moore J, Cox L, Khan DA, Lang D, Nicklas RA, Oppenheimer J, Protnoy JM, Randolph C, Schuller DE, Spector SL, Tilles S, Wallace D. The diagnosis and management of anaphylaxis practice parameter: 2010 update. J Allergy Clin Immunol. 2010;126(3):477-80.

10. Maurer M, Magerl M, Ansotegui I, Aygoren-Pursun E, Betschel S, Bork K, Bowen T, Balle Boysen H, Farkas H, Grumach AS, Hide M, Katelaris C, Lockey R, Longhurst H, Lumry WR, Martinez-Saguer I, Moldovan D, Nast A, Pawankar R, Potter P, Riedl M, Ritchie B, Rosenwasser L, Sanchez-Borges M, Zhi Y, Zuraw B, Craig T. The international WAO/EAACl guideline for the management of hereditary angioedema-the 2017 revision and update. Allergy. 2018;73(8):1575-96.

11. Greve J, Bas M, Hoffmann TK, Schuler PJ, Weller P, Kojda G, Strassen U. Effect of C1-Esterase-inhibitor in angiotensin-converting enzyme inhibitor-induced angioedema. Laryngoscope. 2015;125(6):198-202.

12. Banerji A, Clark S, Blanda M, LoVecchio F, Snyder B, Camargo CA Jr. Multicenter study of patients with angiotensin-converting enzyme inhibitor-induced angioedema who present to the emergency department. Ann Allergy Asthma Immunol. 2008;100(4):327.

13. Nielsen EW, Gramstad S. Angioedema from angiotensin-converting enzyme (ACE) inhibitor treated with complement 1 (C1) inhibitor concentrate. Acta Anaesthesiol Scand. 2006;50(1):120-2.

14. Leibfried M, Kovary A. C1 esterase inhibitor (Berinert) for ACE inhibitorinduced angioedema: two case reports. J Pharm Pract. 2017;30(6):668-71.

15. Riha HM, Summers BB, Rivera JV, Van Berkel MA. Novel therapies for angiotensin-converting enzyme inhibitor-induced angioedema: a systematic review of current evidence. J Emerg Med. 2017:53(5):662-79.

16. Sanchez-Borges M, Capriles-Hulett A, Caballero-Fonseca F. NSAIDinduced urticaria and angioedema: a reappraisal of its clinical management. Am J Clin Dermatol. 2002;3(9):599-607.

\section{Publisher's Note}

Springer Nature remains neutral with regard to jurisdictional claims in published maps and institutional affiliations.
Ready to submit your research? Choose BMC and benefit from:

- fast, convenient online submission

- thorough peer review by experienced researchers in your field

- rapid publication on acceptance

- support for research data, including large and complex data types

- gold Open Access which fosters wider collaboration and increased citations

- maximum visibility for your research: over $100 \mathrm{M}$ website views per year

At BMC, research is always in progress.

Learn more biomedcentral.com/submissions 